\title{
OPTIMIZATION OF PLASMA DEPOSITION AND ETCHING PROCESSES FOR COMMERCIAL MULTICRYSTALLINE SILICON SOLAR CELLS
}

\author{
D. S. Ruby', W. L. Wilbanks ${ }^{2}$, C. B. Fleddermann ${ }^{2}$, M. D. Rosenblum ${ }^{3}$, S. Roncin ${ }^{4}$ and S. Narayanan ${ }^{4}$ \\ ${ }^{1}$ Sandia National Laboratories, Albuquerque, NM 87185-0752 \\ ${ }^{2}$ University of New Mexico, Albuquerque, NM 87131 \\ ${ }^{3}$ ASE Americas, Inc., Billerica, MA 01821 \\ ${ }^{4}$ Solarex (a business unit of Amoco/Enron Solar), Frederick, MD 21701
}

\begin{abstract}
We conducted an investigation of plasma deposition and etching processes on full-size multicrystalline (mc-Si) cells processed in commercial production lines; so that any improvements obtained will be immediately relevant to the PV industry. In one case, we performed a statistically designed multiparameter experiment to determine the optimum PECVD-nitride deposition conditions specific to EFG silicon from ASE Americas, Inc. In a related effort, we studied whether plasma-etching techniques can use standard screen-printed gridlines as etch masks to form self-aligned, patterned-emitter profiles on ma-Si cells from Solarex Corp. Our initial results found a statistically significant improvement of about half an absolute percentage point in cell efficiency when the self-aligned emitter etchback was combined with the PECVD-nitride surface passivation treatment. Additional improvement is expected when the successful bulk passivation treatment is also added to the process.
\end{abstract}

\section{INTRODUCTION}

The use of Plasma-Enhanced Chemical Vapor Deposition (PECVD) as a low-temperature surface passivation technique for silicon solar cells is a topic of increasing importance. PECVD is now widely recognized as a potentially cost-effective, performance-enhancing technique that can provide surface passivation and produce an effective antireflection coating layer at the same time [1]. For some solar-grade silicon materials, it has been observed that the PECVD process results in the improvement of bulk minoritycarrier diffusion lengths as well, presumably due to bulk defect passivation [2].

In order to gain the full benefit from improved emitter surface passivation on cell performance, it is necessary to tailor the emitter doping profile so that the emitter is lightly doped between the gridlines, but heavily doped under them [3]. This is especially true for screen-printed gridlines which require very heavy doping beneath them for acceptably low contact

This work was supported by the U. S. Department of Energy under contract DE-AC04-94AL85000. resistance. This selectively patterned emitter doping profile has historically been obtained by using expensive photolithographic or screen-printed alignment techniques and multiple high-temperature diffusion steps $[3,4]$.

We have attempted to build on a self-aligned emitter etchback technique first described by Spectrolab [5]. In addition to the gridline-masked, plasma-etchback of the emitter they developed, we have included plasmahydrogenation treatments for bulk defect passivation followed by PECVD-nitride deposition for surface passivation and antireflection coating.

\section{EXPERIMENTAL PROCEDURE}

\section{ASE Americas EFG-silicon}

We conducted our investigation on EFG cells using a response surface methodology approach described in Ref. 6 . We began with a main-effects experimental design. Then, a quadratic interaction experiment followed which varied only the most important factors to find conditions for peak efficiency. Finally, a deposition using the predicted optimum parameters was performed to confirm the prediction.

The plasma-nitride depositions were performed using a modified Pacific Western Coyote PECVD reactor. This is a commercial, RF parallel-plate reactor operating at $13.56 \mathrm{MHz}$ with large batch-size and high-throughput potential. Reaction gases for nitride deposition were a $3 \%$ mixture of silane in nitrogen and pure ammonia.

Full-area solar cells were processed in the standard manner on the ASE production line except for when the cells were extracted for the nitride depositions. In this way, any improvements in performance could most easily be incorporated into ASE's process.

\section{Solarex cast multicrystalline silicon}

These cells received Solarex's standard production line processing through the printing and firing of the gridlines. Then, the cells underwent Reactive lon Etching (RIE) for 3 
minutes to increase the sheet resistance of the emitters to 80-100 ohms/square. They were plasma-etched in a Technics PE II-A reactor using pure SF 6 at a power of $10 \mathrm{~W}$ and a pressure of $100 \mathrm{mT}$ Trr. Then, the cells received either an ammonia-plasma hydrogenation treatment (Hpassivation) or a silicon-nitride deposition (PECVD-nitride), both found to be effective for bulk and surface passivation in String Ribbon ${ }^{\mathrm{TM}}$ mc-Si [2]. They were then returned to the Solarex production-line for final cell processing.

\section{RESULTS - Solarex}

The selective-emitter plasma etchback process is described in Figure 1.

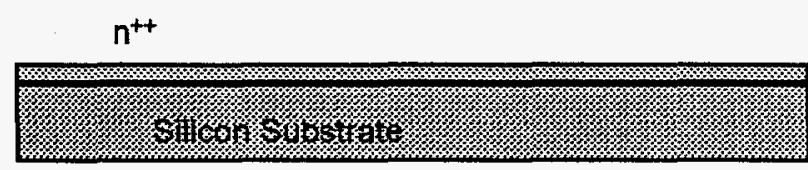

1. Heavy phosphorus diffusion -good for gettering.

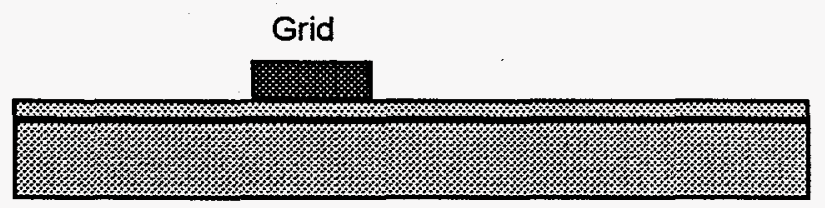

2. Apply front grid -standard commercial metallization.

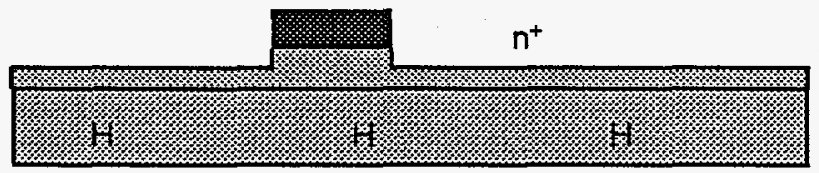

3. Plasma etch emitter and use grid to mask etch beneath grid - self aligned.

Hydrogen-plasma for bulk passivation.

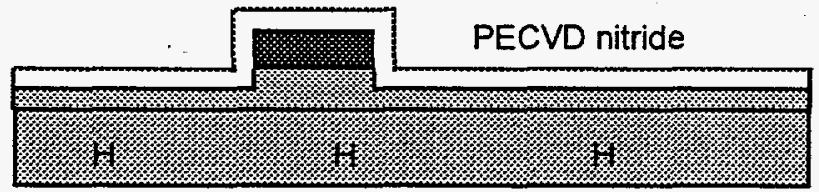

\section{PECVD film for surface passivation and ARC -} same reactor for low cost.

Figure 1. Process sequence for self-aligned emitter etchback. The emitter etchback can be performed after the hydrogenplasma treatment to remove surface damage. However, in this work, the plasma-etching was done first.

There were four groups of $102.6-\mathrm{cm}^{2}$ Solarex cells processed as described in Table 1.
Table 1. Four processing sequences each applied to 12 Solarex mc-Si cells using matched material from the same ingot and in most cases with the same grain structure.

\begin{tabular}{|c|c|c|c|c|}
\hline Eff. (\%) & $\operatorname{Isc}(A)$ & $V_{o c}(m V)$ & $F F(\%)$ & $R_{s}(m \Omega)$ \\
\hline \multicolumn{5}{|c|}{ Group 1. Control Cells: No emitter etchback, $\mathrm{TiO}_{2} \mathrm{ARC}$} \\
\hline 12.6 & $2.91 \pm 02$ & $586 \pm 1$ & $75.5 \pm 0.7$ & \\
\hline \multicolumn{5}{|c|}{ Group 2. Plasma Etchback, $\mathrm{TiO}_{2} \mathrm{ARC}$} \\
\hline $12.2+0.1$ & $2.93 \pm 02$ & $580 \pm 1$ & $73.4 \pm 0.4$ & $15.0 \pm 1.0$ \\
\hline \multicolumn{5}{|c|}{ Group 3. Plasma Etchback, $\mathrm{H}$-passivation, $\mathrm{TiO}_{2} \mathrm{ARC}$} \\
\hline $12.8 \pm 0.3$ & $2.97 \pm 02$ & $585 \pm 1$ & $75.4 \pm 1.5$ & $10.7 \pm 0.5$ \\
\hline \multicolumn{5}{|c|}{ Group 4. Plasma Etchback, PECVD-nitride ARC, FGA } \\
\hline $13.0 \pm 0.1$ & $3.00 \pm 01$ & $587 \pm 1$ & $75.3 \pm 0.2$ & $10.7 \pm 0.5$ \\
\hline
\end{tabular}

The cells from group 2 suffered an efficiency loss due primarily to loss of $V_{O c}$ as expected, since the etched-back emitter is now transparent to minority carriers, which now recombine at the unpassivated front surface. An additional loss in FF is due to the increase in series resistance because of the extra sheet resistance of the etched-back emitter. In an optimized sequence, the cells would have more closelyspaced gridlines to compensate for this. In addition, an extra-heavy emitter doping could be performed, possibly resulting in additional gettering of bulk impurities, which could then be etched away. Also, heavier doping under the gridlines would better isolate them and reduce contact recombination. Finally, the heavier doping would also reduce the contact resistance that often limits screen-printed cell performance. The lack of current loss in these cells indicates that any increase in surface recombination is compensated for by reduced emitter recombination in the now lightly doped emitter.

The group 3 celis have regained most of the $V_{o c}$ loss, probably due to the compensating effect of reduced bulk recombination from the hydrogenation treatment. Interestingly, this is accompanied by a reduction of the series resistance, which is in agreement with observations by Wenham et al., who attributed this to a decrease in the contact resistance of the screen-printed gridlines [7]. This, in combination with the benefits of heavier emitter doping mentioned above, would address many of the shortfalls which have been ascribed to the screen-printing process.

The cells from group 4 have totally regained their initial $V_{o c}$ values and begin to show a significant $3 \%$ gain in $l_{s c}$ now that the surface of the transparent emitter is passivated by the nitride film. The effect of the plasma-nitride deposition on reducing the gridline contact resistance is still apparent, resulting in an overall average increase in efficiency of almost half an absolute efficiency point. Even better results are expected when the nitride passivation is combined with bulk hydrogenation and the benefits of heavy emitter doping.

Internal quantum efficiency curves of typical cells from groups 1,3 , and 4 are shown in Figure 2. LBIC scans showed that the cells from group 2 did not have the same grain structure as the others, and so it was not possible to find the same "median" grain from cells of group 2 on which to measure the IQE. 


\section{DISCLAIMER}

Portions of this document may be illegible in electronic image products. Images are produced from the best available original document. 


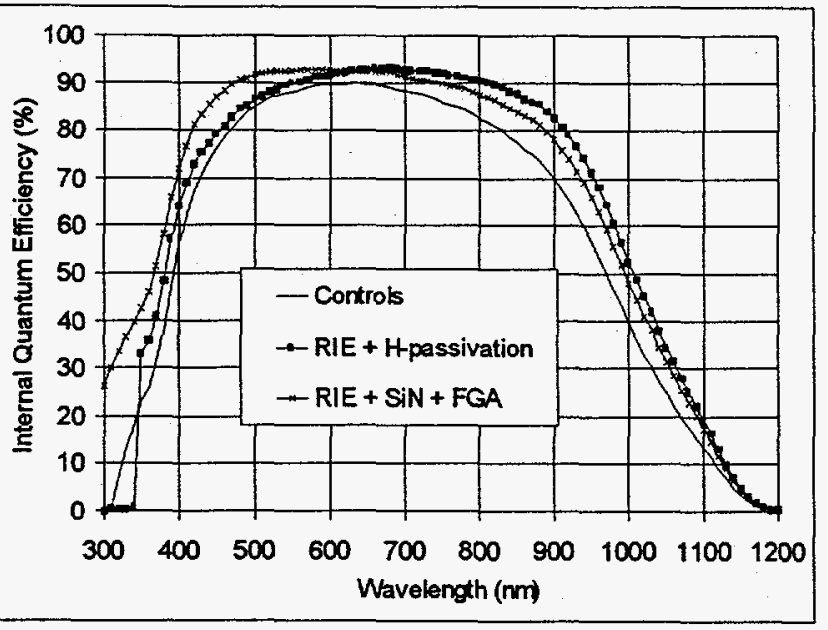

Figure 2. IQE curves of three Solarex cells representative of groups 1, 3, and 4 described in Table 1.

The IQE curves show that while both plasma treatments increased the red-response relative to the control cell, the $\mathrm{NH}_{3}$-hydrogenation treatment had the biggest effect. It is also clear that the nitride-ARC resulted in the best blue response due to its better passivation of the emitter surface. In fact, the IQE $(400-\mathrm{nm})$ value $(73 \%)$ is almost as high as that obtained previously on this material (78\%) using a nitride coating optimized for low surface recombination [6]. This shows that the RIE process may not have damaged the emitter surface significantly.

\section{RESULTS - ASE Americas}

\section{Main-Effects Experiment}

The parameters investigated in the main-effects experiment are shown in Table 2. Because previous work has shown that an in-situ hydrogen or ammonia rf-plasma treatment prior to a PECVD-nitride deposition promotes bulk defect passivation [2], we included a hydrogen or ammonia rfplasma pretreatment as a factor. We also studied whether the predeposition of a thin, $20-\mathrm{nm}$ silicon-nitride protective layer before performing the plasma treatment would serve to minimize surface damage. We also included the duration of the plasma pretreatment as a factor. The other variables are shown in the table.

It was found that a 30-minute plasma pretreatment resulted in both higher $V_{O C}$ and $J_{S c}$, but the choice between whether hydrogen or ammonia should be used can be based upon cost of implementation. The protective film resulted in marginally higher currents, but had no effect on voltage, as might be expected if its main benefit was to protect the emitter surface. The plasma power had no effect. The pretreatment and deposition temperature had the largest effect on cell performance, with the higher temperature preferred for both Voc and Jsc. The higher silane-toammonia ratio was also preferred for both parameters, while the higher deposition power resulted in higher currents only. Cells using the preferred conditions had Voc's up to $47 \mathrm{mV}$
Table 2. Parameters used for the Main-Effects Experiment

\begin{tabular}{|l|c|c|}
\hline Parameter [units] & $\begin{array}{c}\text { Minimum } \\
\text { Value }\end{array}$ & $\begin{array}{c}\text { Maximum } \\
\text { Value }\end{array}$ \\
\hline $\begin{array}{l}\text { Hydrogen or ammonia plasma } \\
\text { pretreatment }\end{array}$ & Hydrogen & Ammonia \\
\hline $\begin{array}{l}\text { Duration of plasma pretreatment } \\
\text { [min] }\end{array}$ & 0 & 30 \\
\hline $\begin{array}{l}\text { Thickness of silicon-nitride } \\
\text { protective film [nm] }\end{array}$ & 0 & 20 \\
\hline $\begin{array}{l}\text { RF-power during plasma } \\
\text { pretreatment [W] }\end{array}$ & 40 & 100 \\
\hline $\begin{array}{l}\text { Temperature of pretreatment and } \\
\text { deposition [ }{ }^{\circ} \mathrm{C} \text { ] }\end{array}$ & 275 & 375 \\
\hline $\begin{array}{l}\text { Silane/ammonia flow ratio during } \\
\text { deposition [sccm/sccm] }\end{array}$ & 10 & 18 \\
\hline RF-power during deposition [W] & 70 & 100 \\
\hline
\end{tabular}

higher and $J_{S c}$ 's $6.5 \mathrm{mAVcm}^{2}$ higher than cells using the poorest conditions.

\section{Quadratic Experiment}

The main-effects results led to the retention of 4 of the original 7 factors. The pretreatment type was set to ammonia for convenience using a low power of $40 \mathrm{~W}$ to reduce the potential for surface damage, and the deposition power was set to $70 \mathrm{~W}$ for best uniformity. Because it was thought that the speed of the belt through the gridline firing furnace would interact with the various densities of nitride films obtained, the belt speed was varied from $15 \%$ lower to $15 \%$ higher than its standard value. A post-deposition Forming Gas Anneal (FGA) was omitted from the maineffects experiment, but included as a factor in the quadratic since it was shown to be important in previous studies [6].

Table 3. Parameters used for the Quadratic Experiment

\begin{tabular}{|l|c|c|}
\hline Parameter [units] & $\begin{array}{c}\text { Minimum } \\
\text { Value }\end{array}$ & $\begin{array}{c}\text { Maximum } \\
\text { Value }\end{array}$ \\
\hline $\begin{array}{l}\text { Duration of ammonia plasma } \\
\text { pretreatment [min] }\end{array}$ & 0 & 45 \\
\hline $\begin{array}{l}\text { Thickness of silicon-nitride } \\
\text { protective film [nm] }\end{array}$ & 0 & 20 \\
\hline $\begin{array}{l}\text { Temperature of pretreatment and } \\
\text { deposition [ }{ }^{\circ} \text { ] }\end{array}$ & 300 & 400 \\
\hline $\begin{array}{l}\text { Silane/ammonia flow ratio during } \\
\text { deposition [sccm/sccm] }\end{array}$ & 10 & 22 \\
\hline Post-deposition FGA temperature & 300 & 400 \\
\hline Gridline-firing belt speed & Std. $-15 \%$ & Std. $+15 \%$ \\
\hline
\end{tabular}

The results of the quadratic experiment are contour plots of the measured variables, which in this case were illuminated cell performance parameters. The response surface for cell efficiency near the highest maximum is shown in Figure 3 . It predicts an efficiency over $13.5 \%$ in a corner of the parameter space where all the parameters are set to their maximum or minimum values. This behavior suggests that even better results may be obtainable by extending the ranges of these parameters. 


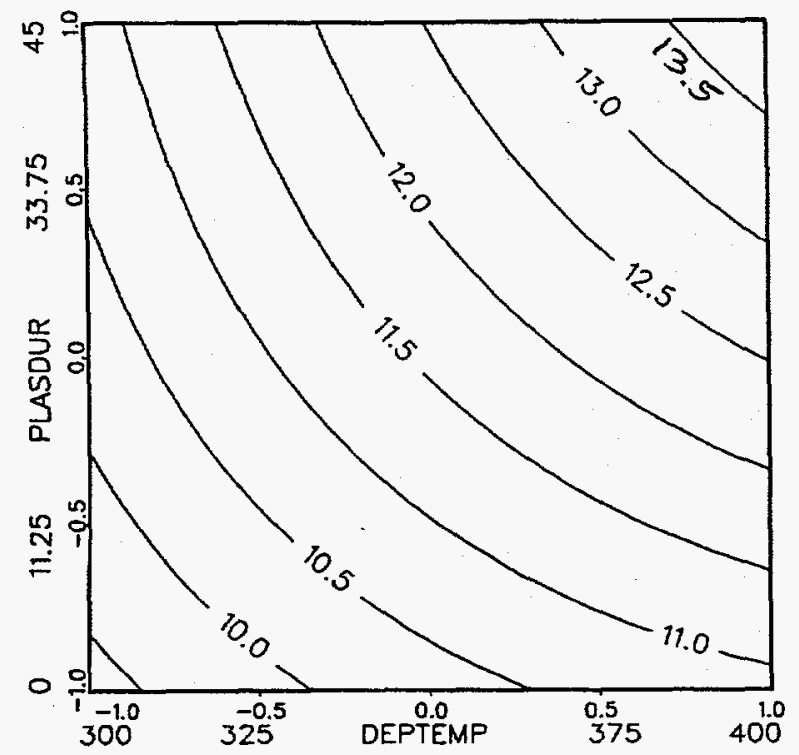

Figure 3. Response surface plot of cell efficiency showing contours of constant efficiency (\%) as a function of plasma pretreatment duration ( $\mathrm{min}$ ) and silicon-nitride deposition temperature $\left({ }^{\circ} \mathrm{C}\right)$. The protective film thickness is fixed at its maximum value while the other variables are set to their minimum values.

Unfortunately, the $95 \%$ confidence limits associated with this contour plot show a statistical uncertainty of 3 percentage points in the upper-right corner due to material and process variability, implying that cells fabricated using these parameters could have an efficiency anywhere between 10.5 and $16.5 \%$. Indeed, when 5 cells were processed using this recipe, the average efficiency was only $9.8 \%$, with the best cell reaching $10.5 \%$. While this is marginally within the expected uncertainty limits, it is not as good as we had hoped for. It was found that these 5 cells suffered from low fillfactors due to higher non-ideal diode recombination $(n>2)$ compared to the best cells in the quadratic experiment that formed the basis for the prediction. Apparently, the fill-factor is a very sensitive function of the deposition parameters which cannot be modeled accurately using a simple quadratic approximation. Higher order models will have to be used to correctly predict the optimum combination. If the fill factors of these five cells had been comparable to those in the quadratic, their average efficiency would have been $11.2 \%$, still low, but well within the confidence limits.

\section{CONCLUSIONS}

This investigation has determined that RIE is compatible with using standard, commercial screen-printed gridlines as etch masks to form self-aligned, selectively-doped emitter profiles. This process results in reduced gridline contact resistance, an undamaged emitter surface easily passivated by plasmanitride, and a less heavily doped emitter between gridines for reduced emitter recombination. It allows for heavier doping beneath the gridlines for even lower contact resistance, reduced contact recombination, and better bulk defect gettering. Future work in this area will incorporate the heavier emitter doping as well as performing the bulk hydrogenation before the RIE step so that surface damage from the bulk passivation step can be removed or reduced. This will be compared with the use of a protective nitride film before hydrogenation. Finally, all three plasma processes, the bulk passivation, emitter etchback, and nitride surface passivation will be combined for the synergistic additive effect of their benefits.

A more sophisticated model of higher order than a quadratic which takes into account the sensitive interactions between all of the processing variables is needed to predict the behavior of overall solar cell performance. In addition, larger sample sizes are needed to reduce the amount of uncertainty in the predictions.

\section{ACKNOWLEDGEMENTS}

The authors would like to thank J. M. Gee for initially suggesting the self-aligned emitter etchback concept, and W. K. Schubert for his help in this area. We are also grateful to the processing staff at Sandia's PDFL and the Solarex and ASE Americas production lines for the cell processing. Many thanks also go to $L$. Irwin for the cell measurements.

\section{REFERENCES}

[1] Z. Chen, P. Sana, J. Salami, and A. Rohatgi, "A Novel and Effective PECVD SiO2/SiN Antireflection Coating for Si Solar Cells, " IEEE Trans. Elect. Dev., 40, June 1993, pp. 1161-1165.

[2] D.S. Ruby, W.L. Wilbanks, C.B. Fleddermann, and J.I. Hanoka, "The Effect of Hydrogen-Plasma and PECVDNitride Deposition on Bulk and Surface Passivation in StringRibbon Silicon Solar Cells," Proc. 13th EPSEC, October 1995, pp. 1412-1414.

[3] A. Blakers et al., "22.8\%-Efficient Silicon Solar Cell," Appl. Phys. Lett. 55, 1989, pp. 1363-1395.

[4] J. Coppye et al., "Non-Conventional Emitters for Polycrystalline Silicon Solar Cells," Proc. 10 $10^{\text {th }}$ EPSEC, April 1991, pp. 657-660.

[5] N. Mardesich, "Solar Cell Efficiency Enhancement by Junction Etching and Conductive AR Coating Processes," Proc. $15^{\text {th }}$ PVSC, May 1981, pp. 446-449.

[6] D.S. Ruby, W.L. Wilbanks, and C.B. Fleddermann, "A Statistical Analysis of the Effect of PECVD Deposition Parameters on Surface and Bulk Recombination in Silicon Solar Cells, " Proc. $1^{\text {st }}$ WCPEC, Dec. 1994, pp. 1335-1338.

[7] S.R. Wenham, M.R. Willison, S. Narayanan, and M.A Green, "Efficiency Improvement in Screen-Printed Polycrystalline Silicon Solar Cells by Plasma Treatments," Proc. $18^{\text {th }}$ PVSC, Oct. 1985, pp. 1008-1013. 


\section{DISCLAIMER}

This report was prepared as an account of work sponsored by an agency of the United States Government. Neither the United States Government nor any agency thereof, nor any of their employees, makes any warranty, express or implied, or assumes any legal liability or responsibility for the accuracy, completeness, or usefulness of any information, apparatus, product, or process disclosed, or represents that its use would not infringe privately owned rights. Reference herein to any specific commercial product, process, or service by trade name, trademark, manufacturer, or otherwise does not necessarily constitute or imply its endorsement, recommendation, or favoring by the United States Government or any agency thereof. The views and opinions of authors expressed herein do not necessarily state or reflect those of the United States Government or any agency thereof. 